\title{
Interspecific variation in total phenolic content in temperate brown algae
}

\author{
Anna Maria Mannino, Valentina Vaglica, Elisabetta Oddo \\ Department of Biological, Chemical and Pharmaceutical Sciences and Technologies, Section of Botany and Plant \\ Ecology, University of Palermo, Italy
}

\begin{abstract}
Marine algae synthesize secondary metabolites such as polyphenols that function as defense and protection mechanisms. Among brown algae, Fucales and Dictyotales (Phaeophyceae) contain the highest levels of phenolic compounds, mainly phlorotannins, that play multiple roles. Four temperate brown algae (Cystoseira amentacea, Cystoseira compressa, Dictyopteris polypodioides and Padina pavonica) were studied for total phenolic contents. Total phenolic content was determined colorimetrically with the Folin-Ciocalteu reagent. Significant differences in total phenolic content were observed between leathery and sheetlike algae and also within each morphological group. Among the four species, the sheet-like alga $D$. polypodioides, living in the upper infralittoral zone, showed the highest concentration of phenolic compounds. These results are in agreement with the hypothesis that total phenolic content in temperate brown algae is influenced by a combination of several factors, such as growth form, depth, and exposition to solar radiation.
\end{abstract}

Correspondence: Anna Maria Mannino, Department of Biological, Chemical and Pharmaceutical Sciences and Technologies, Section of Botany and Plant Ecology, University of Palermo, Via Archirafi 38, I90123 Palermo, Italy.

Tel: +3909123891218 - Fax: +390916165997

Email: annamaria.mannino@unipa.it

Key words: External and internal factors; Mediterranean Sea; Phaeophyceae; Secondary metabolites; Total phenolic content.

Contributions: AMM and EO conceived and designed the experiments, performed the laboratory analyses and analyzed the data, wrote the manuscript; VV collected samples, performed the laboratory analyses and participated in data analysis. All authors read and approved the final manuscript.

Conflict of interest: the authors declare no potential conflict of interest.

Received for publication: 17 January 2017.

Accepted for publication: 7 February 2017.

CCopyright A.M. Mannino et al., 2017

Licensee PAGEPress, Italy

Journal of Biological Research 2017; 90:6578

doi:10.4081/jbr.2017.6578

This article is distributed under the terms of the Creative Commons Attribution Noncommercial License (by-nc 4.0) which permits any noncommercial use, distribution, and reproduction in any medium, provided the original author(s) and source are credited.

\section{Introduction}

Environmental variables together with biotic factors strongly drive growth, reproduction and survival of macroalgae. ${ }^{1,2}$ In response to variations of abiotic and biotic factors and different environmental stresses, seaweeds are able to produce and accumulate secondary metabolites that function as defence compounds. ${ }^{3,4}$ Among secondary metabolites, polyphenols are commonly found in macroalgae. ${ }^{5}$ Brown algae (Phaeophyceae) present a high content of phenols, mainly phlorotannins, that are halogenated oligomers and polymers of phloroglucinol $(1,3,5-$ trihydroxybenzene). ${ }^{5}$ The majority of these molecules are stored in special vesicles (physodes) within the cells and some are constituents of cell walls. ${ }^{6,7}$ Among Phaeophyceae, Dictyotales and Fucales are particularly rich in these compounds that may constitute up to $30 \%$ of the dry weight (DW) of these algae. ${ }^{8}$

These molecules, that certainly represent a cost for the algae in terms of increased metabolic demand and decreased growth rates, ${ }^{9}$ may function as defence against grazers, epiphytes and fouling, and as protection against solar radiation, especially UV radiation. ${ }^{6,10}$ Moreover, they have various biological activities together with therapeutic, antioxidant, cytotoxic and antimicrobial properties. ${ }^{4}$ Recently, it has been also hypothesized they may have a role in the success of invasive species. ${ }^{11}$

Phlorotannin concentration can vary within and among species, being affected by seaweed size, age, thallus structure and morphology, ontogenetic stages and environmental factors (e.g. bathymetric gradients, sea surface temperature, photosynthetically active radiation levels, UV radiation and salinity), but also in relation to geography and reef morphology. $6,10,12,13$

In the Mediterranean Sea, essentially a tideless sea, seaweeds inhabiting the infralittoral fringe, characterized by regular emersion as a result of wave movements, experience harsher environmental stress conditions (e.g. partial desiccation and higher irradiances) than those living in the infralittoral zone, constantly submerged. To cope with these environmentally stressful conditions, algae have developed efficient mechanisms of protection such as the production of phlorotannins. These compounds can also vary throughout the year and their seasonal variations are species specific. ${ }^{14-16}$

The aim of this study was to estimate total phenolic content in four Mediterranean brown algae. In particular, we analysed two leathery algae inhabiting the infralittoral fringe, Cystoseira amentacea (C. Agardh) Bory and C. compressa (Esper) Gerloff $\&$ Nizamuddin, and two sheet-like algae living in the upper infralittoral zone, Dictyopteris polypodioides (A.P. De Candolle) J.V. Lamouroux and Padina pavonica (Linnaeus) Thivy. 


\section{Materials and Methods}

\section{Study area and sampling}

Samples were collected in the Marine Protected Area (MPA) Capo Gallo-Isola delle Femmine, located along the north-western coast of Sicily (NW Mediterranean Sea; N38 12'35"; E13 $\left.{ }^{\circ} 17^{\prime} 06^{\prime \prime}\right)$. Thalli $(\mathrm{n}=5)$ of each species were collected from exposed rocky shores (Barcarello Point) once in summer. For each species, undamaged thalli of the same length and therefore presumably of the same age were collected with a hammer and chisel, at sunrise.

After collection, thalli were placed in plastic bags filled with seawater, for transportation within $1 \mathrm{~h}$ to the wet laboratory at the University of Palermo. In the laboratory, thalli were gently washed with demineralised water to remove detritus and epiphytes and identified with the aid of a stereo microscope and analytical keys. ${ }^{17}$

\section{Preparation of algal extracts}

Approximately $30 \mathrm{~g}$ of algal samples were removed from the middle portion of each thallus $(n=5)$, washed with demineralised water and oven-dried at $50{ }^{\circ} \mathrm{C}$ for $48 \mathrm{~h}$. Dry samples were pulverised with mortar and pestle and $2 \mathrm{~g}$ (dry weight, DW) of each sample were extracted with $25 \mathrm{~mL}$ of $96 \%(\mathrm{v} / \mathrm{v})$ ethanol in centrifuge tubes in a $37^{\circ} \mathrm{C}$ water bath for $2.5 \mathrm{~h}$. The mixture was centrifuged at $2200 \mathrm{~g}$ for $10 \mathrm{~min}$ and the supernatant was collected for further analyses.

\section{Determination of total phenolic content}

Total phenolic content (TPC) was determined colorimetrically with the Folin-Ciocalteu reagent (Sigma-Aldrich Chemie, Steinheim, Germany), using phloroglucinol as the reference standard. ${ }^{18,19}$ The Folin-Ciocalteu method was chosen because it provides more consistent results and is less affected by interfering non-phenolic compounds than other colorimetric methods. ${ }^{20,21}$

Briefly, $0.4 \mathrm{~mL}$ of the ethanol extract was transferred into a test tube containing $0.8 \mathrm{~mL}$ of the $10 \%$ Folin-Ciocalteu-phenol reagent. After $3 \mathrm{~min}, 1.6 \mathrm{~mL}$ of a $10 \%$ sodium carbonate solution was added. The contents of the tube were mixed thoroughly using a glass rod and left to stand at room temperature for $1 \mathrm{~h}$. After the reaction, the absorbance of the samples was measured with a spectrophotometer (DU 800, Beckman Coulter Inc., Fullerton, CA, USA) at $750 \mathrm{~nm}$. TPC was expressed as phloroglucinol equivalents in percentage of DW $(\% \mathrm{DW})$.

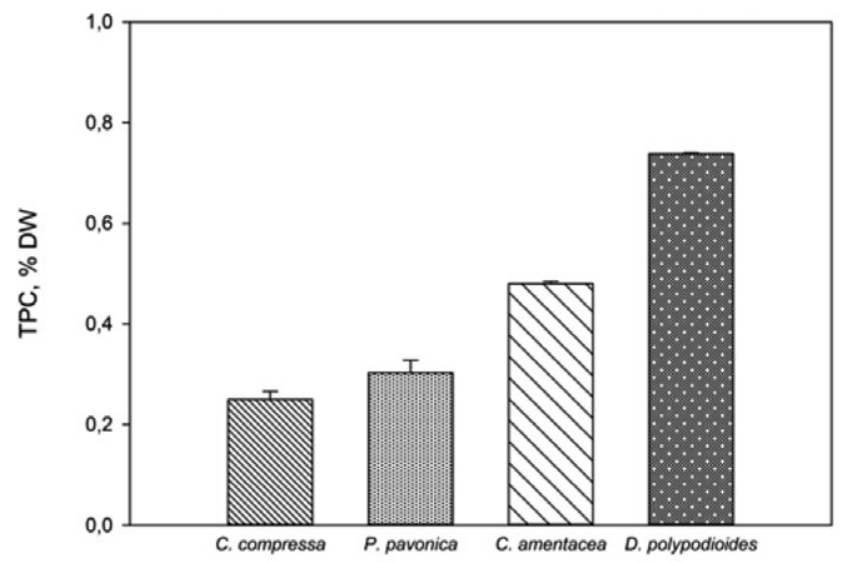

Figure 1. Variations of total phenolic content in the four examined species. Bars represent mean \pm standard deviation $(n=5)$.

\section{Statistical analysis}

All analyses were run in duplicate, and values are expressed as mean \pm standard deviation (SD). Statistical analysis was carried out using SigmaPlot 12 software (Systat Software, Inc., San Jose, CA, USA). The significance of differences in TPC among the four species was tested with a one-way ANOVA. To satisfy the criteria of normality and variance homogeneity, data were square-transformed prior to performing ANOVA. Fisher's LSD post hoc tests were performed when data showed significant differences $(\mathrm{P}<0.05)$.

\section{Results}

TPC differed significantly among the four analysed species (Figure 1; Table 1). D. polypodioides showed significantly higher phenolic content $(0.74 \pm 0.001 \%$ of DW) than the other species whereas C. compressa displayed the lowest value $(0.25 \pm 0.016 \%$ of DW). Differences in TPC between D. polypodioides and each of the other seaweeds, $C$. amentacea $(\mathrm{P}<0.05), C$. compressa $(\mathrm{P}<0.001)$ and P. pavonica $(\mathrm{P}<0.001)$, resulted also significant.

TPC differed significantly between the two leathery algae $(\mathrm{P}<0.05), C$. amentacea $(0.48 \pm 0.06 \%$ of $\mathrm{DW})$ and $C$. compressa $(0.25 \pm 0.02 \%$ of DW), and between the two sheet-like algae $(\mathrm{P}<0.001)$, D. polypodioides $(0.74 \pm 0.001 \%$ of $\mathrm{DW})$ and $P$. pavonica $(0.30 \pm 0.02 \%$ of DW).

\section{Discussion}

The mean TPC values of the analysed species, ranging from $0.25 \pm 0.02 \%$ to $0.74 \pm 0.001 \%$ of DW, are consistent with those reported in previous studies for brown algae. ${ }^{12,21}$

Variations in reported TPC among brown algae are partly attributed to differences in the methods used both in sample preparation and phenol extraction, since different solvents vary in their extraction efficiency. ${ }^{20,22,23}$ As we used the same method in this interspecific analysis of TPC, differences can be attributed to other factors such as thallus morphology, life cycle, bathymetric level and grazing pressure.

Thallus morphology significantly affects the algal palatability so sheet-like algae, as a consequence of their high palatability, ${ }^{24}$ produce high amounts of phenols. This was the case for the sheetlike alga $D$. polypodioides, in which we found a higher phenolic content than in the leathery Cystoseira species. On the contrary, we found a low TPC in the sheet-like alga P. pavonica. However, this species presents consistent blade calcification, making $P$. pavonica a hardly palatable species and thus possibly not requiring greater investment in phenols.

Table 1. Results of the one-way ANOVA on total phenolic content of the four species collected at Barcarello Point in summer.

\begin{tabular}{lccccc} 
Source of variation & SS & df & NS & F & P \\
Between groups & 3.825 & 3 & 1.275 & 10.514 & *** \\
Residual & 1.940 & 16 & 0.121 & & \\
\hline Total & 5.765 & 19 & & \\
\hline SS, sum of squares; df, degree of freedom; MS, mean sum of squares. ***P $<0.001$.
\end{tabular}


Dictyopteris polypodioides is a semi-perennant species producing mature fronds in the autumn-spring period while in summer, a period of rest, we only found the mid-rib and the remains of the frond. High TPC is often found in early vegetative phases in order to increase protection in young tissues. ${ }^{21}$ Finding such a high TPC in summer would confirm the need for this alga to invest in defense strategies all year around, to protect both young and adult thalli.

On the contrary, P. pavonica is an annual alga that reaches the maximum development in summer. The low TPC found in the period of maximum development, would confirm the low palatability of adult thalli of this species.

Cystoseira amentacea and C. compressa are semi-perennant algae with adult thalli present in the spring-summer period. These species did not appear to invest highly in the protection of adult thalli in terms of TPC. The differences found between the two Cystoseira species could be related to some differences in thallus structure or in chemical defences. Indeed, we know Cystoseira species differ for the secondary metabolites they produce, ${ }^{25}$ that may also act as defensive metabolites (constitutive or induced).

The bathymetric level may affect TPC differently, acting both on the herbivore pressure and on the exposure to solar radiation. Consumer pressure is generally lowest in wave exposed shores where the feeding ability of most mobile consumers is limited to calm periods. ${ }^{26}$ Therefore, in the infralittoral fringe a greater water movement makes feeding on algae more difficult than in the constantly submerged zones. Our results are consistent with these observations. Indeed, D. polypodioides inhabiting the upper infralittoral zone showed a higher TPC than that found in Cystoseira species inhabiting the infralittoral fringe. Cystoseira species, even though they are leathery algae, are generally considered highly palatable,${ }^{27}$ therefore we expected to find a TPC similar to that of $D$. polypodioides. But since both Cystoseira species live in a wave exposed zone, that makes feeding on algae more difficult, they do not need to invest many resources in defensive metabolites due to a lower grazer pressure. Even though P. pavonica lives in the upper infralittoral zone where herbivore pressure is higher, as mentioned before, blade calcification makes it a less palatable species.

The bathymetric level also affects exposure to solar radiation. Algae such as Cystoseira species, inhabiting the infralittoral fringe, experience regular even if brief emersion of the apical parts of the thalli, whereas algae such as D. polypodioides and P. pavon$i c a$, living in the upper infralittoral zone, are continually submerged. The emersion of thalli, even if incomplete, implies a direct exposure to solar radiation that gradually decreases as it passes through seawater and TPC is affected by environmental factors such as light quantity and quality. ${ }^{6,28,29}$

Therefore, we would have expected a higher phenolic content in algae inhabiting the infralittoral fringe as compared with those growing in the constantly submerged zones, in agreement with the findings of Pavia and Brock. ${ }^{29}$ Instead, our findings are not consistent with these observations, but partially agree with Connan et al. ${ }^{14}$ who found higher TPC in brown algae growing at mid-tide level compared to that of species inhabiting either the low-tide level or the upper mid-littoral fringe. To explain that, the authors hypothesized that mechanisms of photo-protection other than phenol production exist in seaweeds. For example, carotenoids might limit effects of excessive light in plants and maybe act together with phenolic compounds in algal species. ${ }^{14,30}$ Thus the light stressing condition of the emersion phases does not necessarily result in an increase of TPC. On the contrary, no relation between bathymetric level and TPC in Sargassaceae from Brittany (France) was observed. ${ }^{6}$

\section{Conclusions}

Our results seem to confirm that TPC in brown algae is a response to a combination of several factors. ${ }^{7}$ However, due to the complexity of TPC responses in brown algae and the multiple roles of phlorotannins, for a better understanding of this process, it is still necessary to identify which types of phlorotannins are responsible for the different activities in order to clarify who does what.

Since these algae may produce different metabolites in response to stress conditions (grazing, pathogens), the entire range of defensive mechanisms should be studied in more detail. It is also noteworthy that these algae are a source of different bioactive substances, among which phenolic compounds, which deserve great attention for the benefits they may provide for human health.

\section{References}

1. Diaz-Pulido G, Anthony KRN, Kline DI, et al. Interactions between ocean acidification and warming on the mortality and dissolution of coralline algae. J Phycol 2012;48:32-9.

2. Harley CDG, Anderson KM, Demes KW, et al. Effects of climate change on global seaweed communities. J Phycol 2012;48:1064-78.

3. Sudatti DB, Fujii MT, Rodigues SV, et al. Effect of abiotic factors on growth and chemical defense content in Laurencia dendroidea J. Agardh (Ceramiales, Rhodophyta) cultivated clones. Mar Biol 2011;158:1439-46.

4. Pérez MJ, Falqué E, Domínguez H. Antimicrobial action of compounds from marine seaweed. Mar Drugs 2016;14:52.

5. Targett NM, Boettcher AA, Targett TE, Vrolijk NH. Tropical marine herbivore assimilation of phenolic-rich plants. Oecologia 1995;103:170-9.

6. Stiger-Pouvreau V, Jégou C, Cérantola S, et al. Phlorotannins in Sargassaceae species from Brittany (France): interesting molecules for ecophysiological and valorisation purposes. In: Jacquot JP, Gadal P, Bourgougnon N, eds. Advances in botanical research: sea plants. 71. Academic Press: Elsevier; 2014. pp. 379-411.

7. Koivikko R, Loponen J, Honkanen T, Jormalainen V. Contents of soluble, cell-wall-bound and exuded phlorotannins in the brown alga Fucus vesiculosus, with implications on their ecological functions. J Chem Ecol 2005;31:195-212.

8. Targett NM, Arnold TM. Effects of secondary metabolites on digestion in marine herbivores. In: McClintock JB, Baker BJ, eds. Marine chemical ecology. Florida: CRC Press; 2001. pp. 391-411.

9. Hay ME, Fenical W. Marine plant-herbivore interactions: the ecology of chemical defense. Ann Rev Ecol Syst 1988;19: 111-45.

10. Amsler CD, Fairhead VA. Defensive and sensory chemical ecology of brown algae. Adv Bot Res 2006;43:1-91.

11. Harrison MM, Tyler AC, Hellquist CE, Pagano T. Phenolic content of invasive and non-invasive emergent wetland plants. Aquat Bot 2017; 136:146-54.

12. Le Lann K, Connan S, Stiger-Pouvreau V. Phenology, TPC and size-fractioning phenolics variability in temperate Sargassaceae (Phaeophyceae, Fucales) from Western Brittany: native versus introduced species. Mar Environ Res 2012;80:1-11. 
13. Tanniou A, Vandanjon L, Incera M, et al. Assessment of the spatial variability of phenolic contents and associated bioactivities in the invasive alga Sargassum muticum sampled along its European range from Norway to Portugal. J Appl Phycol 2014;26:1215-30.

14. Connan S, Goulard F, Stiger V, et al. Phlorotannins in beltforming brown algae of a sheltered shore. Bot Mar 2004;47:410-6.

15. Mannino AM, Vaglica V, Oddo E. Seasonal variation in total phenolic content of Dictyopteris polypodioides (Dictyotaceae) and Cystoseira amentacea (Sargassaceae) from the Sicilian coast. F1 Medit 2014;24:39-50.

16. Mannino AM, Vaglica V, Cammarata M, Oddo E. Effects of temperature on total phenolic compounds in Cystoseira amentacea (C. Agardh) Bory (Fucales, Phaeophyceae) from southern Mediterranean Sea. Plant Biosyst 2016;150:152-60.

17. Cormaci M, Furnari G, Catra M, et al. Flora marina bentonica del Mediterraneo: Phaeophyceae. Boll Accad Gioenia Sci Nat 2012;45:1-508.

18. Folin O, Ciocalteu V. On tyrosine and tryptophane determinations in proteins. J Biol Chem 1927;12:239-43.

19. Zahra R, Mehrnaz M, Farzaneh V, Kohzad S. Antioxidant activity of extract from a brown alga, Sargassum boveanum. Afr J Biotechnol 2007;6:2740-5.

20. Waterman PG, Mole S. Analysis of phenolic plant metabolites. Oxford: Blackwell Scientific Publications; 1994.

21. Kamiya M, Nishio T, Yokoyama A, et al. Seasonal variation of phlorotannin in sargassacean species from the coast of the Sea of Japan. Phycol Res 2010;58:53-61.
22. Koivikko R. Variation of phlorotannins among three populations of Fucus vesiculosus as revealed by HPLC and colorimetric quantification. J Chem Ecol 2008;34:57-64.

23. Le Lann K, Jégou C, Stiger-Pouvreau V. Effect of different conditioning treatments on total phenolic content and antioxidant activities in two Sargassacean species: comparison of the frondose Sargassum muticum (Yendo) Fensholt and the cylindrical Bifurcaria bifurcata R. Ross. Phycol Res 2008;56:238-45.

24. Steneck RS, Dethier MN. A functional group approach to the structure of algal-dominated communties. Oikos 1994;69: 476-98.

25. Amico V, Giaccone G, Colombo P, et al. Un nuovo approccio allo studio della sistematica del genere Cystoseira C. Agardh. Boll Accad Gioenia Sci Nat 1985;18:887-986.

26. Witman JD, Dayton PK. Rocky subtidal communities. In: Bertness MD, Gaines SD, Hay ME, eds. Marine community ecology. Sunderland, MA: Sinauer Press; 2001. pp. 339-66.

27. Sala E, Boudouresque CF. The role of fishes in the organization of a Mediterranean sublittoral community. I. Algal communities. J Exp Mar Biol Ecol 1997;212:25-44.

28. Shick JM, Lesser MP, Jokiel PL. Effects of ultraviolet radiation on corals and other coral reef organisms. Glob Change Biol 1996;2:527-45.

29. Pavia H, Brock E. Extrinsic factors influencing phlorotannin production in the brown alga Ascophyllum nodosum. Mar Ecol Prog Ser 2000;193:285-94.

30. Cockell CS, Knowland J. Ultraviolet radiation screening compounds. Biol Rev 1999;74:311-45. 